\title{
Effects of infection by the protistan parasite Marteilia refringens on the reproduction of cultured mussels Mytilus galloprovincialis in Galicia (NW Spain)
}

\author{
Antonio Villalba, Susana G. Mourelle, María J. Carballal, M. Carmen López \\ Center of Marine Research, Ministry of Fisheries and Aquaculture of Galicia, PO Box 208, E-36600 Vilagarcía de Arousa, \\ Spain
}

\begin{abstract}
Infection by the protistan Marteilia refringens affects the digestive glands of cultured mussels in Galicia, Spain. Effects of the infection on the reproduction of the mussel were studied at 3 sites. Gonad cycle of mussels involved gametogenesis utilizing stored reserves and leading to spring spawning (conservative strategy). This was followed by various sequences of gonad restoration and spawning utilizing the energy from concurrent feeding directly (opportunistic strategy). $M$. refringens significantly inhibited gonad development in the periods of opportunistic reproductive strategy, proportionally to infection intensity. However, the inhibitory effect was not significant in the period of conservative strategy, probably because mussels had developed storage tissue before the infection progressed. Development of storage tissue was estimated by the abundance of adipogranular (ADG) cells in the mantle. Infection by $M$. refringens was clearly associated with inhibition of ADG cell development. The heavier the infection, the lower the abundance of ADG cells. Differences in abundance of ADG cells among categories of mussels with different infection intensity were significant at every site. No significant difference in susceptibility to progression of infection was detected between males and females and a similar mortality rate between sexes can be assumed. Evidence suggests that stress following spawning could enhance the progression of the infection.
\end{abstract}

KEY WORDS: Mytilus galloprovincialis - Marteilia refringens - Host-parasite relationship - Mussel reproduction - Gonad cycle Storage tissue Adipogranular cells .

\section{INTRODUCTION}

Studies on the effects of parasitic infection on bivalve molluscs, other than causing mortalities, are scarce (reviewed by Newell \& Barber 1988) although sublethal effects, such as impairment of gametogenesis, can also disturb host population dynamics. Castration of bivalves as a result of gonad destruction by trematod parasites is well documented (reviewed by Lauckner 1983). Impairment of gonad development can also be caused by interference by parasites in energy acquisition, storage and conversion cycles of the host (Ford et al. 1990). Effects of parasites on gametogenesis of bivalve hosts have been reported (Barber et al. 1988a, Ford \& Figueras 1988, Robert et al. 1991).
More than $150000 \mathrm{t}$ of mussels Mytilus galloprovincialis are produced annually in the bays of Calicia, Spain, by suspended culture (Pérez Camacho et al. 1991). Mass raft-culture of mussels markedly determines the ecosystem of these bays, which was dramatically changed after the introduction of mussel culture (Tenore et al. 1982). An infection caused by the protistan Marteilia refringens (Paramyxea) affects cultured mussels. Early stages of the infection are located in the stomach epithelium of the host and spreads through epithelia of digestive diverticula, where sporulation of the parasite takes place. Its pattern of progression, prevalence, geographic distribution and association with mortality have been reported elsewhere (Villalba et al. 1993). This paper deals with the effects of the infection on the reproduction of cultured mussels. The 


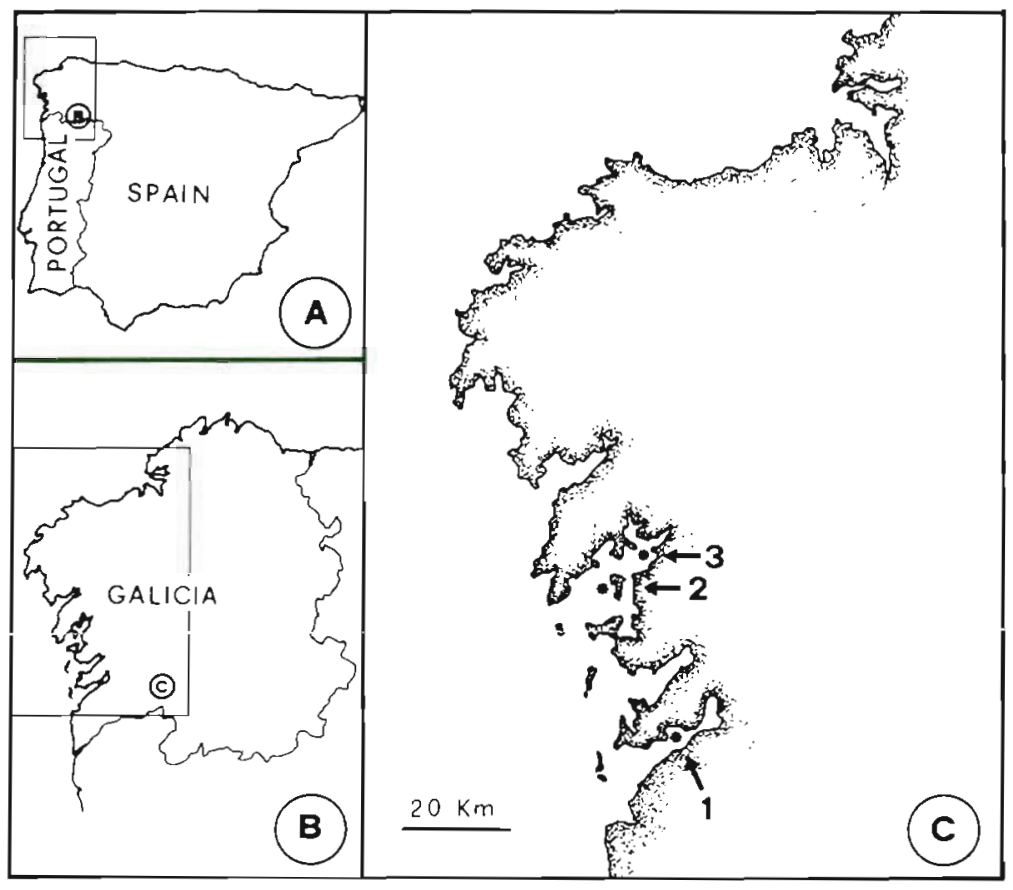

Fig. 1. Location of experimental cultures (*) in bays off Galicia, Spain. Site 1 is located in Vigo Bay; Sites 2 \& 3 in Arousa Bay microscopy for disease diagnosis and analysis of gonad condition.

Rating of infection intensity. Each sampled mussel was rated according to the degree of infection, using a scale based on the intensity of infection (Villalba et al. 1993): no infection (NI), when no parasite was detected; light infection (LI), when the parasites were confined to the stomach epithelium or reached primary ducts at most; moderate infection (MI), when a few digestive tubules were infected; and heavy infection $(\mathrm{HI})$, when infection had spread through the digestive diverticula (more than $10 \%$ of the digestive tubules visible in a nilsiological sectionj.

Rating of gonad development. Morphological condition of the gonad was classified according to the scheme proposed by Lubet (1959): stage 0, resting stage; stage I, multiplication of gonia; stage II, progression of gametogenesis; stage III $A$, ripe gonad; stage III $B$, spawned gonad; stage III $C$, restoring stage; and stage III $D$, reabsorbing stage

objectives of this study were to determine whether infection by $M$. refringens has any influence on gonad development and energy storage, whether females and males show different susceptibility to the infection, and whether postspawning stress enhances the progression of the infection.

\section{MATERIALS AND METHODS}

Experimental cultures and sampling of mussels. Experimental cultures used for this study were described in a previous paper (Villalba et al. 1993). Three culture sites (1, $2 \& 3$ ) that showed higher prevalences of Marteilia refringens (op. cit.) were used for this study (Fig. 1). Cultures were started in February 1988 by tying mussel seed ( $2 \mathrm{~cm}$ long) on ropes hung from floating rafts at Sites $2 \& 3$. After 6 mo, the culture ropes were thinned and mussels were transfered onto new ropes. Experimental culture at Site 1 began with the thinning-out process, in September 1988. Cultures were terminated when market size $(7 \mathrm{~cm}$ long) was exceeded, in August and September 1989.

Samples of 30 mussels were taken monthly from each experimental site. An approximately $5 \mathrm{~mm}$ thick section of tissue containing gill, visceral mass and mantle lobes was excised from every sampled specimen, fixed in Davidson's solution and embedded in paraffin; $6 \mu \mathrm{m}$ thick sections were stained with Harris' hematoxylin and eosin and examined under light
Rating of storage tissue development. Two types of storage cells occur in the mantle of mussels: vesicular cells and adipogranular (ADG) cells (Bayne et al. 1982). Abundance of ADG cells was used in this study as an index of the level of stored reserves. Abundance was quantified using a scale ranging from 0 , when no ADG cell was found, to 5, for the maximum degree of abundance.

Statistical analysis. Differences in gonad development, ADG cell abundance, and sex among mussels with different infection intensities were analyzed by $G$-tests of independence with contingency tables (Sokal \& Rohlf 1981). Table columns were the numbers of mussels in each category of gonad condition, abundance of ADG cells, and sex respectively. Table rows were the categories of infection intensity. For differences in gonad condition at each site, samples of the whole culture period were pooled because of the lack of mussels in some category of infection intensity in some monthly samples from Sites 1 \& 2. In addition, samples from Site 3 corresponding to 4 different periods of the gonad were treated separately, since infection prevalence was higher at this site.

Goodness of fit of the sex ratio to $1: 1$ was tested by chi-square tests (Sokal \& Rohlf 1981). Association between postspawning stress and progression of infection was assessed in 2 different ways. (1) Mussels sampled from Site 3 in months in which both pre- and postspawning gonad stages occurred were pooled into 2 groups: those showing prespawning stages and those 
in postspawning stages. Association between infection intensity and pre- or postspawning gonad stage was assessed by $G$-tests of independence. (2) Spearman rank correlation coefficients $\left(r_{S}\right)$ between the percentage of mussels with a heavy infection of every monthly sample and the percentage of mussels in a postspawning stage in the same month were calculated using SOLO statistical software.

Mussels with light and moderate infections were pooled together because of the lack of significant differences between these categories for every considered variable. Samples of the period from the start of cultures to the first detection of cases of infection were not considered for statistical analysis. Mussels infected by trematods were not used in any comparison because of the well-known detrimental effects of these parasites on the gonad of the host (reviewed by Lauckner 1983).

\section{RESULTS}

\section{Infection and gonad development}

It was observed at every site that, after pooling monthly samples, the lower the intensity of infection, the higher was the percentage of mussels showing stages of gonad progression (I, II, III A \& III C). On the other hand, the higher the intensity of infection, the higher was the percentage of mussels showing stages of gonad regression (III D) or resting (0) (Fig. 2).

Differences in gonad development between mussels with heavy infection and the remaining mussels were significant at every site. Differences between noninfected mussels and those with light or moderate infection were not significant at any site (Table 1).

\section{Intensity of infection and gonad condition in 4 different periods at Site 3}

According to the gonad condition observed in every noninfected mussel from Site 3,4 different periods were distinguished in the mussel gonad cycle at this site (Fig. 3C): (1) the period September-December 1988 was characterized by active gametogenesis; (2) during the period January-March 1989 most mussels remained ripe; (3) the period April-May 1989 was characterized by early spring spawning and subsequent restoration of the gonad to ripeness; and (4) in the period June-September 1989, after a new spawning, reabsorption of the gonad took place, although some mussels were involved in new restoring and spawning sequences. The resting stage was very reduced and a new gametogenic cycle started at the end of this period.
SITE 1

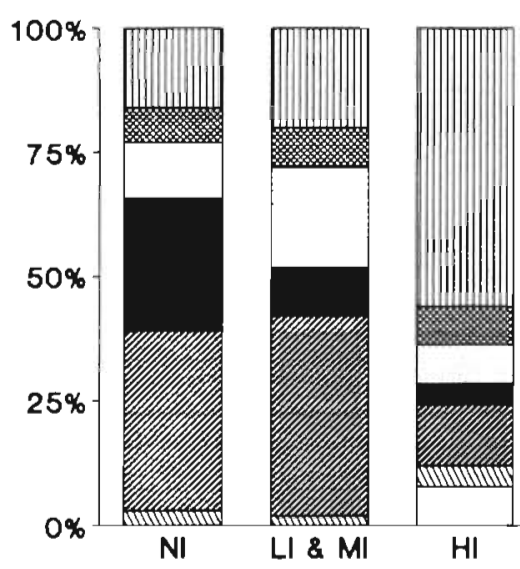

SITE 2

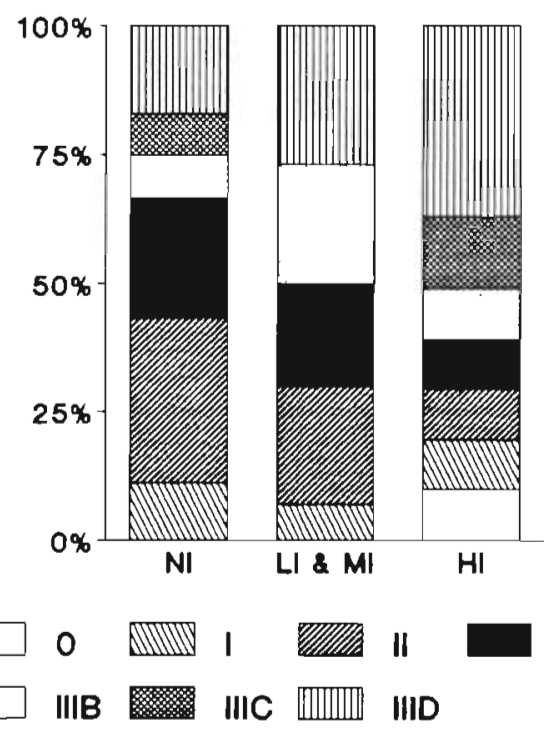

SITE 3

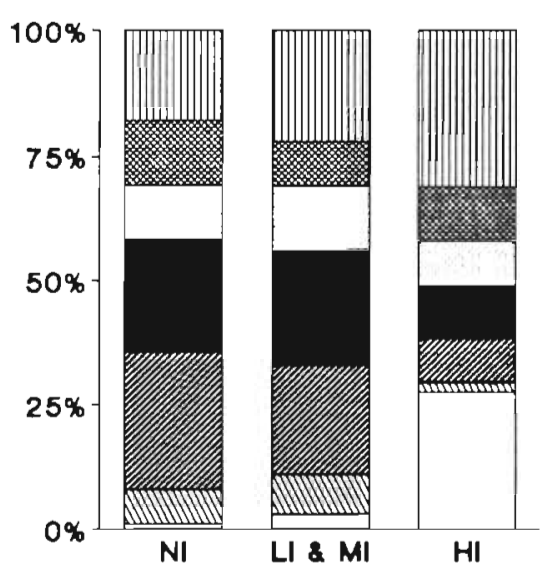

IIIA

Fig. 2. Mytilus galloprovincialis infected by Marteilia refringens. Distribution of mussels according to gonad stage and intensity of infection at the 3 sites. Samples of the whole culture period were pooled. Bars correspond to infection intensity classes - NI: noninfected; LI \& MI: lightly and moderately intected; HI: heavily infected. Percentages of mussels corresponding to each gonad stage are identified by different bar patterns - 0: resting; I: multiplication of gonia; II: progression of gametogenesis; III A: ripe; III B: spawned; III C: restoration; III D: reabsorption 
A
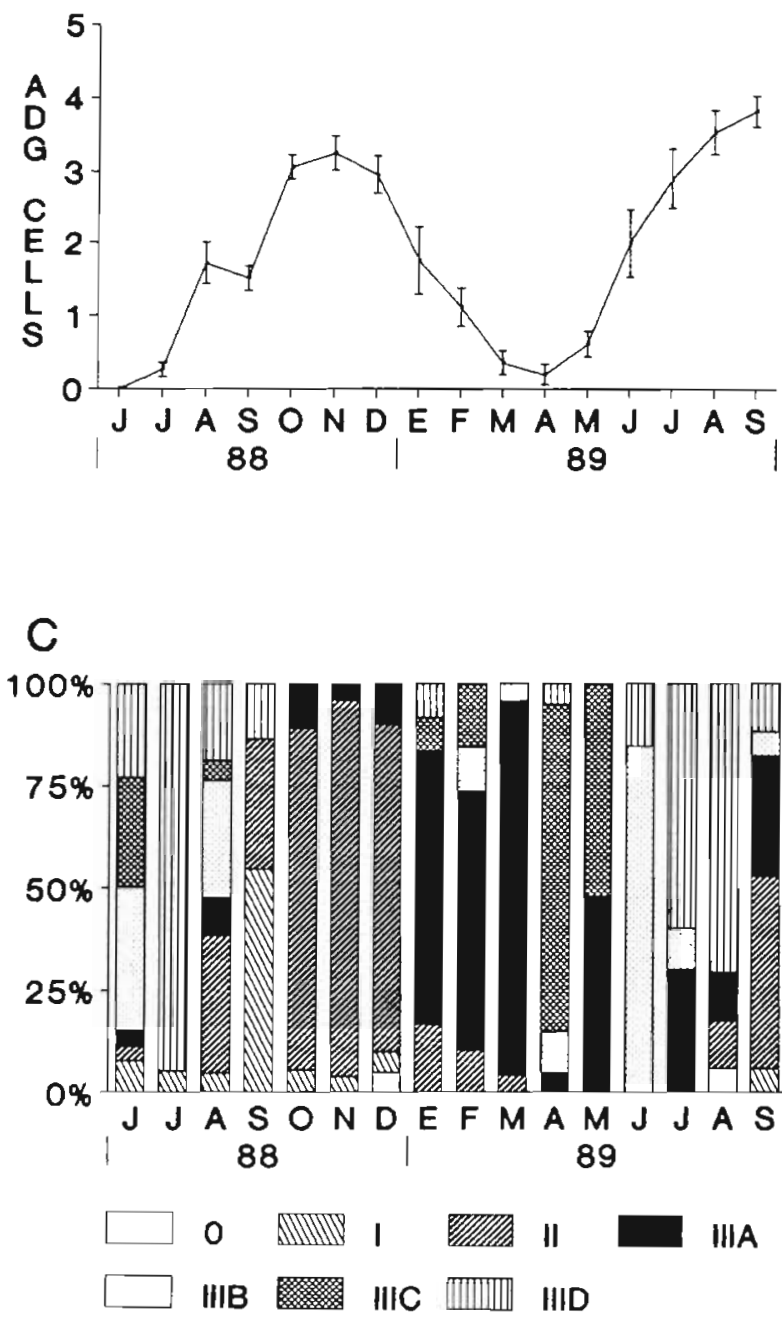

Table 1. Mytilus galloprovincialis infected by Marteilia refringens. Results of $G$-tests for independence between gonad stage and intensity class of infection at each site. $n s: p>0.05$; p $<0.05 ; \cdots p<0.001$

\begin{tabular}{|c|c|c|c|c|}
\hline Site & Infection intensity & $\mathrm{N}$ & df & $G$ \\
\hline \multirow[t]{4}{*}{1} & NI vs LI and MI & 323 & 5 & $7.40 \mathrm{~ns}$ \\
\hline & NI vs HI & 301 & 5 & $14.70^{\circ}$ \\
\hline & HI vs LI and MI & 58 & 5 & $7.26 \mathrm{~ns}$ \\
\hline & HI vs NI, LI and MI & 341 & 5 & $1.4 .04^{\circ}$ \\
\hline \multirow[t]{4}{*}{2} & NI vs LI and MI & 409 & 4 & $8.66 \mathrm{~ns}$ \\
\hline & NI vs HI & 400 & 4 & $11.54^{\circ}$ \\
\hline & HI vs LI and MI & 51 & 4 & $4.60 \mathrm{~ns}$ \\
\hline & HI vs NI, LI and MI & 430 & 4 & $10.88^{\circ}$ \\
\hline \multirow[t]{4}{*}{3} & NI vs LI and MI & 420 & 6 & $7.72 \mathrm{~ns}$ \\
\hline & NI vs HI & 352 & 6 & $57.96^{\cdots} \cdot$ \\
\hline & HI vs LI and MI & 162 & 6 & $27.50^{\cdots} \cdots$ \\
\hline & HI vs NI, LI and MI & 467 & 6 & $53.30^{\cdots} \cdots$ \\
\hline
\end{tabular}

B

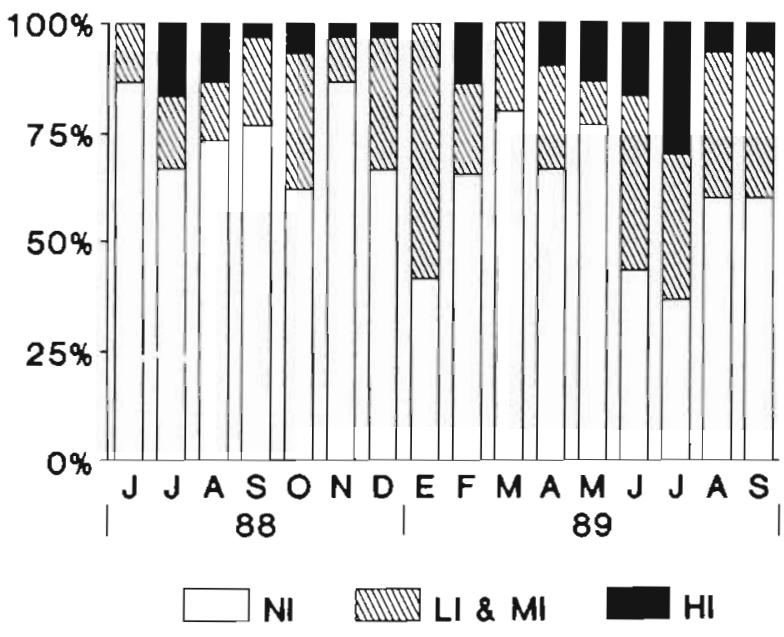

Fig. 3. Mytilus galloprovincialis infected by Marteilia refringens. Monthly variation of mean abundance of ADG cells and gonad stages of noninfected mussels and intensity of infection throughout the culture period at Site 3 . The period between the start of culture and the first detection of infection is not shown. (A) Variation (mean $\pm \mathrm{SE}$ ) of abundance of ADG cells corresponding to the noninfected mussels of each monthly sample. (B) Distribution of mussels in each monthly sample by infection intensity. Percentages of mussels corresponding to each class of infection intensity are identified by different bar patterns (see Fig. 2). (C) Distribution of noninfected mussels in each monthly sample by gonad stage. Percentages of mussels corresponding to each gonad stage are identified by different bar patterns (see Fig. 2)

There was no significant difference in gonad development among infection intensity classes in the period of active gametogenesis. However, differences between the class of heavy infections and the other 2 classes grouped were significant in the remaining periods (Table 2 ). In the period characterized by predominance of ripe stage, heavily infected mussels showed higher percentages of spawned and reabsorbing stages. In the period characterized by gonad restoration, around $50 \%$ of heavily infected mussels showed reabsorbing stage. In the period June-September $1989,50 \%$ of heavily infected mussels showed resting stage and no case of restoration or ripe gonad was found in this infection intensity class (Fig. 4).

\section{Infection and ADG cells}

Abundance of ADG cells was used in this study as an index of the level of stored reserves. The monthly variation of the mean abundance of ADG cells occurring in the mantle of noninfected mussels throughout the culture period at Site 3 involved the following pattern: ADG cells started to appear in the mantle by July 1988 . 
SEP-DEC 1988

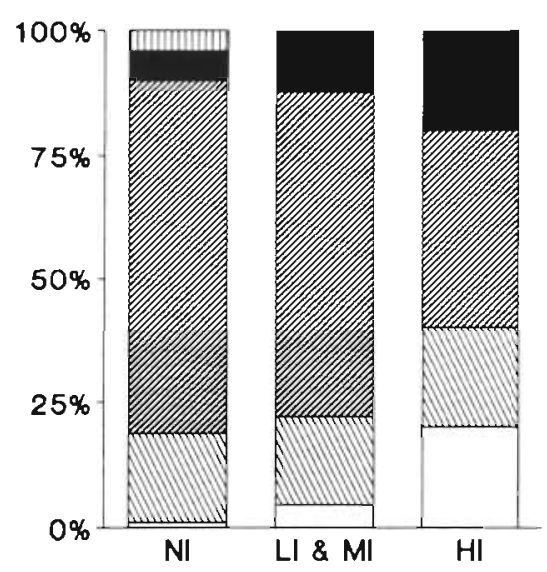

JUN-SEP 1988

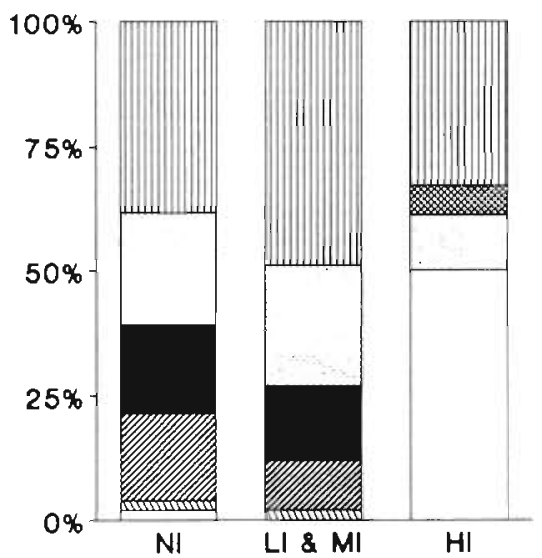

JAN-MAR 1989

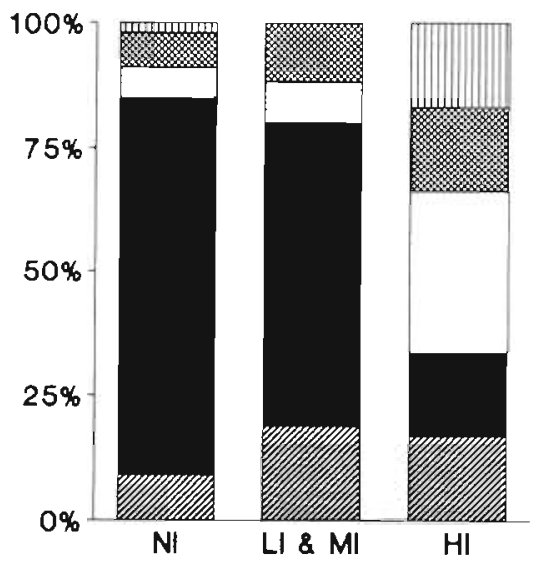

APR-MAY 1989

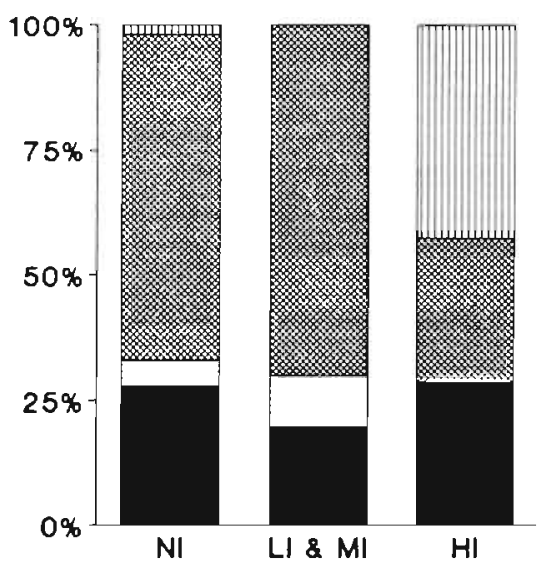

Their abundance increased during the summer and the highest values were recorded during autumn, when gametogenesis was in progress. As mussels became ripe, the abundance of ADG cells decreased. A new cycle in the occurrence of ADG cells in the mantle started after the spring spawning (Fig. 3A). Similar patterns of variation were recorded at the other sites.

The percentage of heavily infected mussels without ADG cells was 70 to $80 \%$ at the 3 sites, whereas it did not exceed $50 \%$ in any of the other classes of infection intensity at the 3 sites (Fig. 5). Differences in abundance of ADG cells between pairs of infection intensity classes were significant in most cases (Table 3).

\section{Sex and infection}

Differences in the sex ratio among different infection intensity classes were not significant at any site. Sex ratios did not significantly deviate from $1: 1$ in any infection intensity class at the 3 sites (Table 4 ).
Table 2. Mytilus galloprovincialis infected by Marteilia refringens. Results of G-test for independence between gonad stage and intensity class of infection in 4 periods at Site 3. ns: $\mathrm{p}>0.05 ; \cdot \mathrm{p}<0.05{ }^{*} \cdot \mathrm{p}<0.01 ; \cdots p<0.001$

\begin{tabular}{|c|c|c|c|c|}
\hline Period & Infection intensity & $\mathrm{N}$ & $\mathrm{df}$ & $G$ \\
\hline \multirow{4}{*}{ Sep-Dec 1988} & NI vs LI and MI & 112 & 3 & $3.36 \mathrm{~ns}$ \\
\hline & NI vs HI & 90 & 3 & $4.30 \mathrm{~ns}$ \\
\hline & HI vs LI and MI & 32 & 3 & $1.88 \mathrm{~ns}$ \\
\hline & HI vs NI, l and MI & 117 & 3 & $3.70 \mathrm{~ns}$ \\
\hline \multirow[t]{4}{*}{ Jan-Mar 1989} & NI vs LI and MI & 80 & 3 & $2.14 \mathrm{~ns}$ \\
\hline & NI vs HI & 60 & 3 & $9.64^{\circ}$ \\
\hline & HI vs LI and MI & 32 & 3 & $6.64 \mathrm{~ns}$ \\
\hline & HI vs NI, LI and MI & 86 & 3 & $9.52^{\circ}$ \\
\hline \multirow[t]{2}{*}{ Apr-May 1989} & NI vs HI & 50 & 2 & $9.26^{*}$ \\
\hline & HI vs NI, I and MI & 60 & 2 & $10.38^{\circ}$ \\
\hline \multirow[t]{4}{*}{ Jun-Sep 1989} & NI vs LI and MI & 98 & 3 & $1.60 \mathrm{~ns}$ \\
\hline & NI vs HI & 74 & 3 & $24.98^{\cdots}$ \\
\hline & HI vs LI and MI & 58 & 3 & $22.18 \cdots$ \\
\hline & HI vs NI, LI nd MI & 115 & 3 & $29.56^{\cdots}$ \\
\hline
\end{tabular}


SITE 1

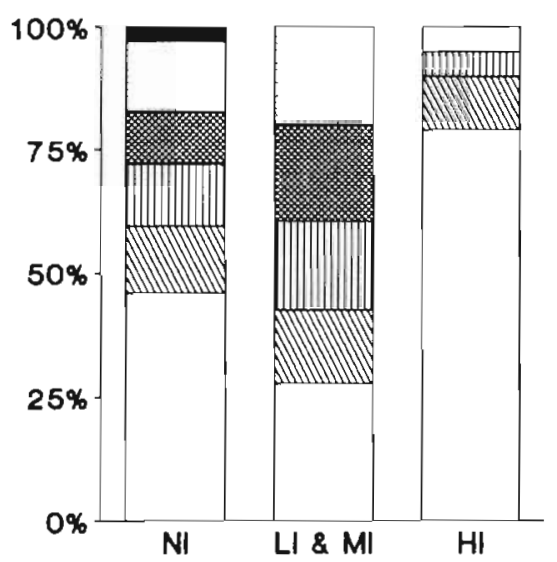

SITE 2

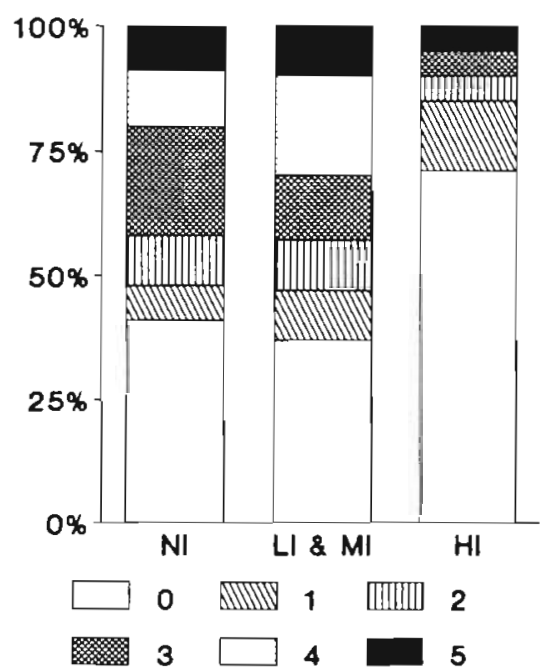

SITE 3

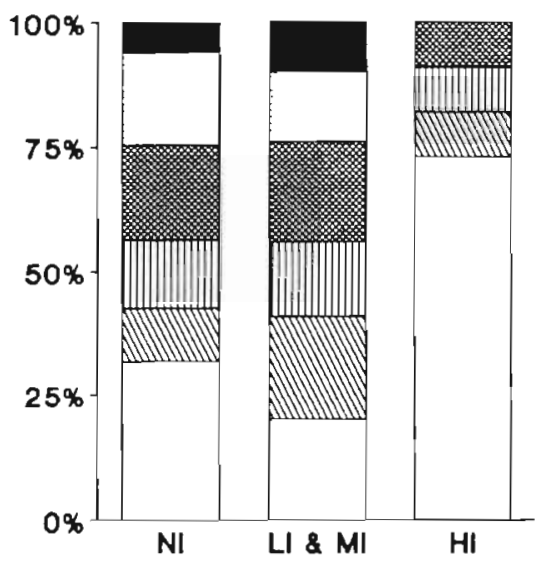

Fig. 5. Mytilus galloprovincialis infected by Marteilia refringens. Distribution of mussels according to abundance of ADG cells in mantle and intensity of infection. Bars correspond to infection intensity classes (see Fig. 2). Percentage of mussels corresponding to each class of abundance of ADG cells (0 to 5$)$ are identified by different bar patterns

\section{Postspawning and progression of the infection}

Prespawning stages (II and III A) and postspawning stages (III B, III C and III D) coexisted in the period January-March 1989 at Site 3 (Fig. 3). In this period, heavy infections were significantly more frequent in mussels after spawning as compared with the other classes of infection intensity (Table 5).

Percentage of postspawning stages (III B, III C \& III D) and percentage of heavily infected mussels in each sample were significantly correlated at Site $2\left(r_{\mathrm{s}}=0.74\right.$, $\mathrm{n}=15, \mathrm{p}<0.01)$ and Site $3\left(r_{\mathrm{S}}=0.73, \mathrm{n}=16, \mathrm{p}<0.01\right)$, but not at Site $1\left(r_{\mathrm{S}}=0.23, \mathrm{n}=12, \mathrm{p}>0.05\right)$ (Fig. 6).

Table 3. Mytilus galloprovincialis infected by Marteilia refringens. Results of $G$-tests for independence between abundance of ADG cells and intensity class of infection at each site. ns: $p>0.05 ;{ }^{\circ} p<0.05 ;{ }^{\cdots} p<0.01 ; \cdots p<0.00$

\begin{tabular}{|c|c|c|c|c|}
\hline Site & Infection intensity & $N$ & $\mathrm{df}$ & $G$ \\
\hline \multirow[t]{4}{*}{1} & NI vs LI and MI & 323 & 2 & $9.26^{\cdots}$ \\
\hline & NI vs HI & 302 & 2 & $6.14^{\circ}$ \\
\hline & HI vs LI and MI & 59 & 2 & $14.34 \cdots$ \\
\hline & HI vs NI, LI and MI & 342 & 2 & $7.36^{\circ}$ \\
\hline \multirow[t]{4}{*}{2} & NI vs LI and MI & 413 & 3 & $2.34 \mathrm{~ns}$ \\
\hline & $\mathrm{NI}$ vs $\mathrm{HI}$ & 404 & 3 & $12.72^{\cdots}$ \\
\hline & HI vs Li and MI & 51 & 3 & $9.32^{*}$ \\
\hline & HI vs NI, LI and MI & 434 & 3 & $12.78 \cdots$ \\
\hline \multirow[t]{4}{*}{3} & NI vs LI and MI & 396 & 3 & $9.78^{\circ}$ \\
\hline & NI vs HI & 330 & 3 & $42.08 \cdots$ \\
\hline & H.I vs LI and MI & 154 & 3 & $39.96 \cdots$ \\
\hline & HI vs NI, LI and MI & 440 & 3 & $36.30 \cdots$ \\
\hline
\end{tabular}

\section{DISCUSSION}

Results demonstrate that there is a negative association between infection by Marteilia refringens and the development of mussel gonad. The heavier the infection, the less developed was the gonad. Nevertheless, differences in gonad development were significant only betwen the class of heavily infected mussels and the noninfected class, and between the former and the other 2 classes grouped, at every site.

Two types of storage cells occur in the mantle of mussels: vesicular cells and ADG cells. Regression of the ADG cells occurs during gametogenesis by a lyso-

Table 4. Mytilus galloprovincialis infected by Marteilia refringens. Sex ratio ( $F: M$ ) for every intensity class of infection at each site. Results of chi-square tests for goodness of fit to a $1: 1$ ratio are shown. Results of comparisons of sex-ratio among intensity classes of infection by $M$. refringens each site, using $G$-tests for independence, are also included. ns: $p>0.05$

\begin{tabular}{|lllcl|}
\hline \multirow{2}{*}{ Site } & $\begin{array}{l}\text { Infection } \\
\text { intensity }\end{array}$ & F:M & $\chi^{2}$ & $G$ \\
\hline 1 & NI & 1.17 & $1.82 \mathrm{~ns}$ & $0.002 \mathrm{~ns}(\mathrm{df}=2)$ \\
& LI and MI & 1.18 & $0.24 \mathrm{~ns}$ & \\
& HI & 1.14 & $0.07 \mathrm{~ns}$ & \\
2 & NI & 0.93 & $0.58 \mathrm{~ns}$ & $0.42 \mathrm{~ns}(\mathrm{df}=2)$ \\
& LI and MI & 1.13 & $0.12 \mathrm{~ns}$ & \\
& HI & 0.80 & $0.22 \mathrm{~ns}$ & \\
& & & & \\
& NI & 1.01 & $0.01 \mathrm{~ns}$ & $3.06 \mathrm{~ns}(\mathrm{df}=2)$ \\
& LI and MI & 1.27 & $1.55 \mathrm{~ns}$ & \\
& Hi & 0.74 & $0.76 \mathrm{~ns}$ & \\
& & & &
\end{tabular}


Table 5. Mytilus galloprovincialis infected by Marteilia refringens. Results of $G$-tests for independence between spawning-related gonad stage (pre-or postspawning) and intensity class of infection in the period January-March 1989 at Site 3. ns: $p>0.05 ; \cdot p<0.05 ; \cdots p<0.01$

\begin{tabular}{|lccc|}
\hline Infection intensity & N & df & $G$ \\
\hline NI vs LI and MI & 78 & 1 & $0.40 \mathrm{~ns}$ \\
NI vs HI & 60 & 1 & $7.10^{\circ}$ \\
Hl vs LI and MI & 30 & 1 & $4.46 \cdots$ \\
HI vs NI, Ll and MI & 84 & 1 & $6.70 \cdots$ \\
\hline
\end{tabular}

somal autophagic mechanism (Bayne et al. 1982, Lowe et al. 1982). Gonad cycle and variation of mean abundance of ADG cells observed in noninfected mussels at Site 3 showed that gametogenesis leading to early spring spawning was accomplished by utilizing storage products accumulated during the previous summer and autumn. Subsequent rapid sequences of gonad restoration and spawning in late spring and summer used the energy coming from concurrent feeding directly. Thus, Mytilus galloprovincialis exhibits both conservative and opportunistic reproductive strategies at this site (Bayne 1976). A similar combination of both strategies was described by Rodhouse et al. (1984) based on mussels $M$. edulis cultured on suspended ropes.

Marteilia refringens infection progresses through the digestive epithelia of mussels (Villalba et al. 1993); therefore, a direct destruction of gonad by the parasite is not observed, but impairment of the processes of food digestion and absorption would be expected. Absorption efficiency is significantly reduced by heavy infections of this parasite (Villalba et al. unpubl.). The inhibitory effect of $M$. refringens on gonad condition varied depending on season. During the periods of active gametogenesis and ripeness, previous to the spring spawning, gonad development was not significantly influenced by infection, probably because mussels had the opportunity to store the required energy for gametogenesis before becoming heavily infected. However, inhibition of gonad development by infection was clear after the spring spawning, when gonad restoration relied on energy from concurrent feeding. Thus, heavily infected mussels did not restore their gonads after the spring spawning and reabsorbed their gonads, whereas most of the remaining mussels recovered and developed ripe gonads. Summer was the period with the highest differences between classes of infection intensity. A proportion of the noninfected mussels showed new sequences of restoration and spawning before reabsorbing their gonads. Most of them started a new gametogenic cycle by the end of this period. On the contrary, most heavily infected

\section{SITE 1}

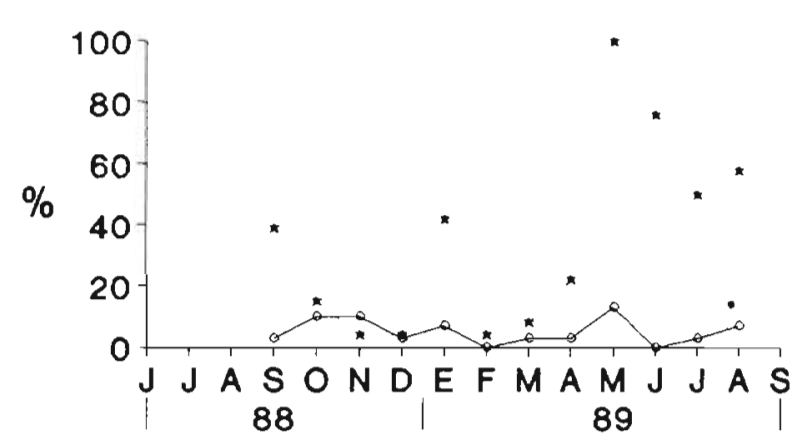

\section{SITE 2}

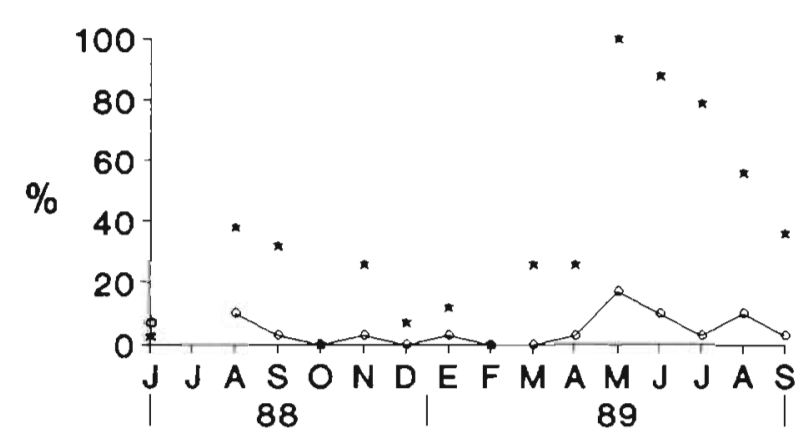

\section{SITE 3}

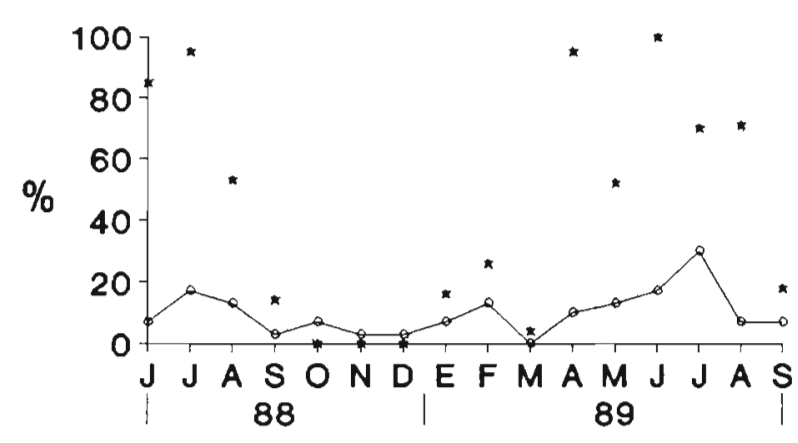

Fig. 6. Mytilus galloprovincials infected by Marteilia refringens. Variation of the percentage of heavily infected mussels (solid line) and the percentage of mussels with gonad postspawning stages (III B + IIl C + III D) (dotted line) throughout the culture period at the 3 sites. Experimental cultures of Sites $2 \& 3$ started in February 1988 and first detection of infection occurred in June 1988. Culture at Site 1 started in September 1988. Site 2 was not sampled in July 1988

mussels reabsorbed their gonads to the resting stage and were not able to start a new gametogenic cycle in September 1989. Mussels with light or moderate infections showed an intermediate position. Robert et al. (1991) found some indication of inhibition of gonad de- 
velopment in edible oysters Ostrea edulis by $M$. refringens. Inhibition of gametogenesis in eastern oysters Crassostrea virginica by the haplosporidian parasite Haplosporidium nelsoni (Barber et al. 1988a, Ford \& Figueras 1988, Ford et al. 1990) and the apicomplexan Perkinsus marinus (Mackin 1962) was also detected.

Inhibition of $A D G$ cell development is clearly associated with Marteilia refringens infection. The heavier the infection, the lower was the abundance of ADG cells in the mantle. Differences were significant among different infection intensity classes at every site with a sole exception. The highest prevalence of $M$. refringens occurred in July, when active energy storage was in progress in noninfected mussels. Those infected mussels that did not store cncrgy would not bo able to develop their gonads properly in autumn (Bayne et al. 1982), and many of them would probably die because of their poor condition. Interference by $M$. refringens in the processes of feeding and absorption of food materials would in part explain the impairment of ADG cell development. In addition, infection is a stressing factor that could induce higher energetic demand on the mussel (host reaction, competition for resources) leading to reallocation of reserves, and thus explaining the loss of ADG cells (Bayne et al. 1982, Love \& Pipe 1986).

Effects on bivalve energy budgets by other parasites have also been reported. The parasite Haplosporidium nelsoni causes significant reduction of clearance rates and condition index of Classostrea virginica (Newell 1985) and depletion of reserves (Barber et al. 1988b). Respiration rates of the oyster are also affected by this parasite in thermal stress conditions (Littlewood \& Ford 1990). Glycogen depletion in oysters Ostrea edulis associated with Marteilia refringens infections was reported (Robert et al. 1991).

No difference in susceptibility to progression of infection was detected between males and females, with regard to sex ratio and infection intensity. Moreover, a similar mortality rate between sexes can be assumed.

The percentage of heavily infected mussels in each monthly sample was significantly correlated with the percentage of mussels in postspawning stages at 2 of the 3 studied sites. Moreover, heavy infections were significantly more frequent in mussels after spawning in the only period in which prespawning and postspawning stages coexisted at Site 3 . These results could suggest that stress after spawning enhances the progression of the infection. On the contrary, Ford \& Figueras (1988) did not find evidence of enhancement of Haplosporidium nelsoni infection in Crassostrea virginica by postspawning stress. Energetic cost of reproduction and subsequent postspawning stress become higher as the mussel grows (Kautsky 1982, Worral \& Widdows 1984, Emmett et al. 1987). That could contribute to explain the lower prevalences observed during the first year of culture at the 3 sites.

Acknowledgements. We are grateful to the mussel farmers Mr Armando Otero, Mr José Padín and Mr Rouco Varela for their cooperation with the experimental cultures. We also thank Dr José Molares for his suggestions on statistical treatment and Dr José Fuentes for critical review of the manuscript. Ms Maribel Meléndez, Ms Teresa Andrade and Ms Elena Penas provided technical assistance for histological technics. This research was supported by funds of the Ministry of Fisheries and Aquaculture of Galicia (Spain).

\section{LITERATURE CITED}

Barber, B. J., Ford, S. E., Haskin, H. H. (1988a). Effects of the parasite MSX (Haplosporidium nelsoni) on oyster (Crassostrea virginica) energy metabolism. I. Condition index and relative fecundity. J. Shellfish Res. 7: 25-31

Barber, B. J., Ford, S. E., Haskin, H. H. (1988b). Effects of the parasite MSX (Haplosporidium nelsoni) on oyster (Crassostrea virginica) energy metabolism. II. Tissue biochemical composition. Comp. Biochem. Physiol. 91A: $603-608$

Bayne, B. L. (1976). Aspects of reproduction in bivalve molluscs. In: Wiley, M. (ed.) Estuarine processes. Academic Press, New York, p. 432-448

Bayne, B. L., Bubal, A., Gabbott, P. A., Livingstone, D. R., Lowe, D. M., Moore, M. N. (1982). Glycogen utilisation and gametogenesis in Mytilus edulis L. Mar. Biol Lett. 3: $89-105$

Emmett, B., Thompson, K., Popham, J. D. (1987). The reproductive and energy storage cycles of two populations of Mytilus edulis (Linné) from British Columbia. J. Shellfish Res. 6: 29-36

Ford, S. E., Figueras, A. J. (1988). Effects of sublethal infection by the parasite Haplosporidium nelsoni (MSX) on gametogenesis, spawning, and sex ratios of oysters in Delaware Bay, USA. Dis. aquat. Org. 4: 121-133

Ford, S. E., Figueras, A. J., Haskin. H. H. (1990). Influence of selective breeding, geographic origin, and disease on gametogenesis and sex ratios of oysters, Crassostrea virginica, exposed to the parasite Haplosporidium nelsoni (MSX). Aquaculture 88: 285-301

Kautsky, N. (1982). Quantitative studies on gonad cycle, fecundity, reproductive output and recruitment in a Baltic Mytilus edulis population. Mar. Biol 68: 143-160

Lauckner, G. (1983). Diseases of Mollusca: Bivalvia. In: Kinne, O. (ed.) Diseases of marine animals, Vol II. Biologische Anstalt Helgoland, Hamburg, p. 477-961

Littlewood, D. T. J., Ford, S. E. (1990). Physiological responses to acute temperature elevation in oysters, Crassostrea virginica (Gmelin. 1791), parasitized by Haplosporidium nelsoni (MSX) (Haskin, Stauber and Mackin, 1966). J. Shellfish Res. 9: 159-163

Lowe, D. M., Moore, M. N., Bayne, B. L. (1982). Aspects of gametogenesis in the marine mussel Mytilus edulis L. J. mar. biol. Ass. U.K. 62: 133-145

Lowe, D. M., Pipe, R. K. (1986). Hydrocarbon exposure in mussels: A quantitative study in the reproductive and nutrient storage cell systems. Aquat. Toxicol. 8: 265-272

Lubet, P. (1959). Recherches sur le cycle sexuel et l'emission 
des gametes chez les Mytilides et les Pectinides (Mollusques Bivalves). Revue Trav. Inst. Péch. marit. 23: $395-545$

Mackin, J. G. (1962). Oyster disease caused by Dermocystidium marinum and other microorganisms in Louisiana. In: Mackin, J G., Hopkins S. H. (eds.) Studies on oysters in relation to the oil industry. Publs Inst. mar Sci. Univ. Texas 7: 132-299

Newell, R. 1. E. (1985). Physiological effects of the MSX parasite Haplosporidium nelsoni (Haskin, Stauber and Mackin) on the American oyster Crassostrea virginica (Gmelin). J. Shellfish Res. 5: 91-95

Newell, R. I. E., Barber, B. J. (1988). A physiological approach to the study of bivalve molluscan diseases. Am. Fish. Soc. Spec Publ. 18: 269-280

Pérez Camacho, A., González, R., Fuentes, J. (1991). Mussel culture in Galicia. Aquaculture 94: 263-278

Robert, R., Borel, M., Pichot, Y., Trut, G. (1991). Growth and mortality of the European oyster Ostrea edulis in the Bay of Arcachon (France). Aquat. liv. Res. 4: 265-275

Rodhouse, P. G., Roden, C. M., Burnell, G. M., Hensey, M. P. McMahon, T., Ottway, B., Ryan, T. H. (1984). Food re-

Responsible Subject Editor: O. Kinne, Oldendorf/Luhe, Germany source, gametogenesis and growth of Mytilus edulis on the shore and in suspended culture: Killary Harbour, lreland. J. mar biol. Ass. U.K. 64: 513-529

Sokal, R. R., Rohlf, F. J. (1981). Biometry, 2nd edn. W. H. Freeman \& Co., New York

Tenore, K. R., Boyer, L. F., Cal, R. M., Corral, J., García Fernández, C., González, N., González-Gurriarán, E.. Hanson, R. B., lglesias, J. B., Krom, M., López-Jamar, E., McClain, J., Pamatmat, M. M., Pérez, A., Rhoads, D. C., de Santiago, G. D., Tietjen, J., Westrich, J., Windom, H. L. (1982). Coastal upwelling in the Rias Bajas, NW Spain: contrasting the benthic regimes of the Rias de Arosa and de Muros. J. mar. Res. 40:701-772

Villalba, A., Mourelle, S. G., López, M. C., Carballal, M. J. Azevedo, C. (1993). Marteiliasis affecting cultured mussels Mytilus galloprovincialis of Galicia (NW of Spain). I. Etiology, phases of the infection, and temporal and spatial variability in prevalence. Dis. aquat. Org. 16: $61-72$

Worrall C. M., Widdows, J. (1984). Investigation of factors influencing mortality in Mytilus edulis L. Mar. Biol. Lett. 5: $85-97$

Manuscript first received: May 10, 1993

Revised version accepted: August 23, 1993 